\title{
Correction to: Detecting focal cortical dysplasia lesions from FLAIR-negative images based on cortical thickness
}

\author{
Cuixia Feng ${ }^{1^{*}}\left(\mathbb{D}\right.$, Hulin Zhao ${ }^{2}$, Maoyu Tian ${ }^{1}$, Miaomiao Lu and Junhai Wen ${ }^{{ }^{*}}$
}

The original article can be found online at https://doi. org/10.1186/s12938-0200757-8.

\section{${ }^{*}$ Correspondence:} 786733550@qq.com; wenjh@bit.edu.cn

${ }^{1}$ Department of Biomedical Engineering, School of Life

Science, Beijing Institute of Technology, Beijing, China Full list of author information is available at the end of the article

\section{Correction to: BioMed Eng OnLine (2020) 19:13 https://doi.org/10.1186/s12938-020-0757-8}

It was highlighted that the original article [1] contained an error in the Quantitative evaluation of Methods. A bracket was misplaced in the formula. This Correction article shows the incorrect and correct formula.

$$
\begin{aligned}
& \text { Incorrect formula } \\
& \qquad \text { Recall }=(\mathrm{TP} / \mathrm{TP}+\mathrm{FN}) \cdot 100
\end{aligned}
$$

\section{Correct formula}

$$
\text { Recall }=\mathrm{TP} /(\mathrm{TP}+\mathrm{FN}) \cdot 100
$$

\section{Author details \\ ${ }^{1}$ Department of Biomedical Engineering, School of Life Science, Beijing Institute of Technology, Beijing, China. ${ }^{2}$ Sixth} Medical Center of PLA General Hospital, Beijing, China.

Published online: 17 March 2020

\section{Reference}

1. Feng C, Zhao H, Tian M, Wen J. Detecting focal cortical dysplasia lesions from FLAIR-negative images based on cortical thickness. BioMed Eng OnLine. 2020;19:13. https://doi.org/10.1186/s12938-020-0757-8.

\section{Publisher's Note}

Springer Nature remains neutral with regard to jurisdictional claims in published maps and institutional affiliations. source, provide a link to the Creative Commons licence, and indicate if changes were made. The images or other third party material in this article are included in the article's Creative Commons licence, unless indicated otherwise in a credit line to the material. If material is not included in the article's Creative Commons licence and your intended use is not permitted by statutory regulation or exceeds the permitted use, you will need to obtain permission directly from the copyright holder. To view a copy of this licence, visit http://creativecommons.org/ licenses/by/4.0/. The Creative Commons Public Domain Dedication waiver (http://creativecommons.org/publicdomain/zero/1.0/) applies to the data made available in this article, unless otherwise stated in a credit line to the data. 